水文・水資源学会誌 J. Japan Soc. Hydrol \& Water Resour. Vol. 15, No. $1(2002) \quad$ pp. $60-69$

\title{
畕場容水量を考慮した流量流積関係式の集中化
}

\section{Lumping of Kinematic Wave Equation Considering Field Capacity}

\author{
市川 温* (京都大学工学研究科) \\ Yutaka ICHIKAWA Faculty of Engineering, Kyoto University \\ 村田康明** （東京大学大学院工学系研究科） \\ Yasuaki MURATA Graduate School of Engineering, University of Tokyo \\ 椎葉充晴* （京都大学工学研究科） \\ Michiharu SHIIBA Faculty of Engineering, Kyoto University
}

\begin{abstract}
This paper describes a method to lump a kinematic wave equation which considers field capacity of hill slope soil layer. The method is based on a method to lump a general kinematic wave equation, which has been developed by the authors. The kinematic wave equation considering field capacity and the method to lump a general kinematic wave equation are firstly shown, followed by the explanation on the method to lump the kinematic wave equation considering field capacity. This kinematic wave equation contains free water content $h_{f}$ in addition to discharge per unit width $q$ and total water content $h$ as state variables in the form of the parameter. Thus the lumping method which has been developed by the authors cannot be applied to this equation as it is. In this paper we develop a way to apply the lumping method to this equation by changing a variable of integration from $h$ to $h_{f}$ in the lumping process. The lumped model derived from the kinematic wave equation considering field capacity is applied to simulate runoff processes of Daido River basin and Katsura River basin. Then effectiveness and problems of the lumping method are verified by comparing the results with the calculation results of a distributed runoff model and the observation results.
\end{abstract}

Key words : Field capacity, Runoff model, Kinematic wave equation, Lumping, Digital topographic information

筆者らが開発してきた，山腹斜面流出系における一般的な流量流糟関俰式を集中化する手法を基礎として，戋場容水量を考虑し た流量流積関係式を集中化する方法について述べる．まずはしめに，固場容水量を考慮した流量流積関係式と，基礎となる集中化 手法の概要について説明し，つぎに，固場容水量を考虑した流量流積関係式に対する具体的な集中化手法を展開する，本流量流積 関係式には，関係する状態量として，単位偪流量 $q$ ，水量 $h$ のほかに，自由水分水量 $h$ が媒介変数の形で含まれており，基礎とする 集中化手法をそのまま適用することができない，本論文では，集中化の過程で行なうhによる積分操作をhでの積分操作に置き換 えることで, 本流量流積関係式の集中化を可能としている，最後に，本流量流積関係式から導出された集中化モデルを大户川流域 と桂川流域に適用し，その結果を分布型モデルによる計算結果および観測結果と比較して，本集中化手法の有奻性と問題点を検証 する。

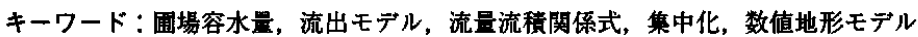

\section{I 、はじめに}

従来の分布型流出モデルは，洪水時の短期出水を 対象としたものが多く，土壤に保持されていた雨水
が時間的に緩やかに流出してくる現象を再現できる モデルはこれまで存在していなかった。これに対し て, 椎葉ら(1998)は, 従来の表面流・中間流統合型 kinematic wave モデル(椎葉, 1983)に莆場容水量の

*京都大学工学研究科土ホシステム工学専攻 $\mathbf{\top} 606-8501$ 京都市左京区吉田本町

Department of Civil Engineering Systems, Faculty of Engineering, Kyoto University, Yoshida Honmachi, Sakyo-ku, Kyoto 606 -8501 Japan

**東京大学大学院工学系研究科都市工学専攻％113-8656 東京都文京区本蚱7-3-1

Department of Urban Engineering, Graduate School of Engineering, University of Tokyo, 7-3-1, Hongo, Bunkyo-ku, Tokyo 113-8656, Japan 
概念を導入することによって，洪水時だけではなく， 低水時の流出計算も可能とする流出モデルを構築し た.これによって, kinematic wave モデルによる 流出計算が, 洪水時から低水時へ，あるいは低水時 から洪水時へと，連続的に接続できるようになった。

さらに椎葉ら (1999b)は，この流出モデルに蒸発 散の機構を導入し，山地流域における河川流況評価 を目的としたモデルを構成している．しかし，この 分布型流出モデルは，計算に非常に多大な時間を要 するという問題点があり，最終的な目的である河川 流域全体の長期的な流況評洒には至っていないのが 現状である。

一方, 筆者ら $(1999 ; 2000)$ は, 分布型流出モデル による計算の負担を軽滅するため，山腹斜面系にお ける雨水流動を逐一追跡計算するのではなく，数值 地形情報を利用して分布型流出モデルを集中化する 手法を展開してきた. 本手法の最大の特徴は, 対象 とする斜面系全体に対するマク口な貯留量流出量関 係式を先験的に与えるのではなく，物理的な基礎式 から出発して, 地形量と水量の空間的分布を考虑し つつ, 斜面系の貯留量と流出量の関係を導出する点 にある。

本論文では, 椎葉ら (1998)が提示した，畨場容水 量を考虑した流量流積関係式を，筆者らが展開して きた手法を用いて集中化する方法について説明する. この流量流積関係式を集中化することによって，雨 水の長期的な流動現象を非常に短時間で計算できる ようになり，たとえば，流域改変に伴う河川流況の 長期的な変動を予測したり，平常時の流出計算と実 時間洪水予測計算を結合するといったことが可能と なる。

\section{II．圆場容水量を考慮した流量流䅪関係式}

畕場容水量を考慮した流量流積関係式は，表面 流・中間流統合型 kinematic waveモ $゙$ ルの流量流 積関係式がベースとなっている．表面流・中間流統 合型 kinematic waveモデルの流量流積関係式を次 に示す。

$$
q=\left\{\begin{array}{l}
a h(0 \leq h<d) \\
\alpha(h-d)^{m}+a h(h \geq d)
\end{array}\right.
$$

ここで, $h$ : 水量 $[\mathrm{m}], q$ : 単位幅流量 $\left[\mathrm{m}^{2} / \mathrm{sec}\right]$, $\alpha=\sqrt{\sin \theta} / n, \theta$ : 斜面勾配 [rad], $n$ : Manning の粗度係数 $\left[\mathrm{m}^{-1 / 3} \mathrm{sec}\right], m$ : 定数 $[-](>1), a(=$ $\left.k \sin \theta / \gamma_{\mathrm{e}}\right)$ : 地中水実質流速 $[\mathrm{m} / \mathrm{sec}], k$ : 透水係 数 $[\mathrm{m} / \mathrm{sec}], \gamma_{e}$ : 表土層有効空隙率 $[$ - $], d\left(=\gamma_{e}\right.$

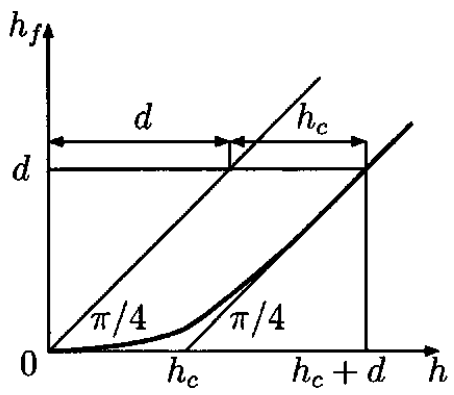

図-1 $h, h$, の関係

Fig. 1 Relationship between $h$ and $h_{f}$

$D)$ : 表土層の空隙部分の深さ $[\mathrm{m}], D$ : 表土層厚 [m] である.

このモデルでは，表土層に侵入した雨は直ちに中 間流あるいは表面流として側方に流動するが，実際 には，表土層に浸透した雨水は主に毛管張力に起因 する土層の保水性に従って, その一部は土層中に貯 留される，その土層の含水率が增大していくとやが て自由水として流れ出す，そのときに土層が保持し ている水量を围場容水量という。普通, 固場容水量 は土層全体に対する水量のことをいうが，本研究で は, 畨場容水量に対応する含水率も圊場容水量と呼 び， $\gamma_{c}$ と表すことにする.

椎葉ら(1998)は， $N>1$ なるパラメ夕を導入し， 表土層の水量 $h[\mathrm{~m}]$ と自由水分水量 $h_{f}[\mathrm{~m}]$ の関係 として次式を提案している.

$$
h=u\left(h_{f}\right)=\left\{\begin{array}{l}
h_{f}+h_{c}\left(1-\left(\frac{d-h_{f}}{d}\right)^{N}\right)^{1 / N} \\
\left(0 \leq h_{f}<d\right) \\
h_{f}+h_{c}\left(h_{f} \geq d\right)
\end{array}\right.
$$

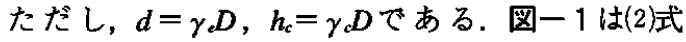
の関係を示したものである.

ここで, 自由水分水量 $h_{f}$ が表面流 - 中間流統合型 流量流積関係式に従うと考え，(1)式のhをhっで置き 換えると，固場容水量を考虑した流量流積関係式が 次式のように得られる.

$$
q=g\left(h_{f}\right)=\left\{\begin{array}{l}
a h_{f}\left(0 \leq h_{f}<d\right) \\
\alpha\left(h_{f}-d\right)^{m}+a h_{f}(h f \geq d)
\end{array}\right.
$$

\section{III. 集中化手法}

\section{1. 基礎となる集中化手法の概要 \\ 1）基本的な考元方}

基本となる考え方は以下のようである．まず，対 象とする山腹斜面系の数值地形モデル(椎葉ほか, 
1999a）を作成する．この数値地形モデルは，グリッ ド状に与えられた標高デー夕を基礎として, 山腹斜 面系を矩形の小斜面の集合体としてモデル化するも のである．以下ではこの小斜面のことを斜面素片と よぶ.つぎに，この地形モデルから得られる地形量 を利用して，流量ならびに通水断面積の空間分布を 定常状態のそれで近似する，最後に，通水断面積を 空間的に積分することによって, 対象とする山腹斜 面系に扔ける貯留量を求め, 貯留量と流出量の集中 化された関係を導出する．ただ，集中化の対象とす る流量流積関係式によっては, 通水断面積の空間積 分を必ずしも解析的に実行できるとは限らないとい うことに留意する必要がある，たとえば，表面流· 中間流統合型の流量流積関係式では, 水量 $h$ を流量 $q$ の関数として表すことができないため, 通水断面 積の空間分布を陽に得ることができず，その結果， 通水断面穦を解析的に積分することができない.そ こで, 本集中化手法では, 貯留量と流出量の関係を 離散的に求め, 離散值の間は, 線形補間で内挿する という工夫を施している. 以下，この離散的な貯留 量と流出量の関係を導出する方法について概述する.

\section{2）基礎式}

集中化の対象とする流量流積関係式を一般的に次 のように書くことにする.

$$
q(x, t)=g(h(x, t))
$$

ただし, $x$ : 空間座標, $t:$ 時間, $q(x, t)$ : 単位幅 流量, $h(x, t):$ 水量である。流量流積関係式には いろいろなタイプが考えられるが,ここではqがh の関数として陽に表され，かつんで積分可能なもの を考える。(4)式をhについて解いた式を，

$$
h(x, t)=f(q(x, t))
$$

と書くことにする. $f$ は, $g$ が $h(x, t)$ のべき乗と いった単純な形であれば，陽に求まるが，たとえば， 表面流・中間流統合型流量流積関保式のように少し 複雑になると, $f$ 陽に求めることはできない.

いま, 対象とする山腹斜面系に, 定常でかつ空間 的に一様な降水が与えられ, 降水流出系が定常状態 になっていると仮定する．このときの降水強度を $\bar{r}$ と書くことにすると, 山腹斜面系内のある地点での 流量は, となる。

この状態において, ある斜面素片の貯留量を求め ることを考える．眝留量を $s$ 書くことにすると，

$$
s=\int_{0}^{L} A(x) d x
$$

$$
=\int_{0}^{\iota} w(x) h(x) d x
$$

である.ただし， $x$ ：当該斜面素片の上端から下流 方向に測った距離, $L$ : 斜面素片の長さ, $A(x)$ : 通 水断面積 $(=w(x) h(x)), w(x)$ : 斜面素片の幅, $h$ $(x)$ : 斜面に対して垂直に測った水量である.また， 降水流出系が定常であるという仮定から, 斜面素片 内の流量は次式のように表される.

$$
\begin{aligned}
Q(x) & =Q(0)+\bar{r} \int_{0}^{x} w\left(x^{\prime}\right) d x^{\prime} \\
& =\bar{r} U+\bar{r} \int_{0}^{x} w\left(x^{\prime}\right) d x^{\prime}
\end{aligned}
$$

$U$ は当該斜面素片の上流域の面積である. 各斜面素 片に対するUは，数值地形モデルにおいて，当該斜 面素片の上流に位置する斜面素片の面積を足し合わ せることで容易に求めることができる.

ここで, 斜面素片は幅一様の矩形であるから，w $(x)$ を

$$
\begin{aligned}
& s=\bar{w} \int_{0}^{L} h(x) d x \\
& Q(x)=\bar{r} U+\overline{r w} \int_{0}^{x} d x^{\prime}=\bar{r} U+\overline{r w} x \\
& q(x)=Q(x) / \bar{w}=\bar{r} U / \bar{w}+\bar{r} x
\end{aligned}
$$

\section{3）貯留量の算出}

各斜面素片の貯留量を求めるには(8)式の積分を実 行すればよいわけだが, しかし（5)式で与えられる fは，先にも述べたように，陽に求まっているとは 限らないため, (8)式の積分をつねに解析的に実行で きるというわけではない. また, 斜面素片にいくつ かの計算断面を設け, 各計算断面の流量に対応する 水量を数值的に求めて，これを数値積分するという 方法も考えられなくはないが, 数值計算による誤差 が発生するという問題がある、そこで, 筆者ら (2000) は, 極力少ない数値計算で(8)式の積分を実行 する方法を提案している．以下にその方法の概要を 示す.

流量 $q$ と空間座標 $x$ には(10)式で示される関係があ るので, (8)式の積分をxによる積分からqによる積

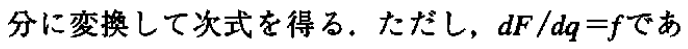
る.

$$
\begin{aligned}
s & =\bar{w} / \bar{r} \int_{q(0)}^{q(L)} f(q) d q \\
& =\bar{w} / \bar{r}[F(q(L))-F(q(0))]
\end{aligned}
$$

図一 2 は, $f, g, F$ の関係を模式的に示したもの

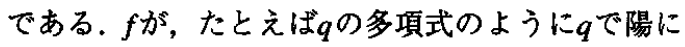



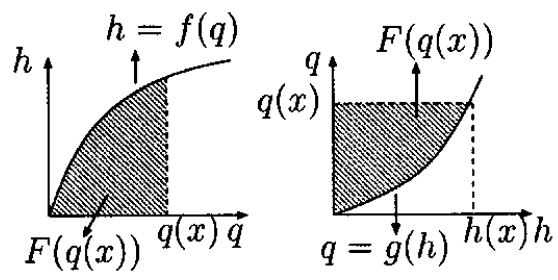

図一2 $f, g, F$ の関係

Fig. 2 Relationship among $f, g$ and $F$

表され，かつ解析的に積分可能であれば，Fは容易 に計算できるが，ここでは $q$ がhの関数として与え られていることを想定しているので，一般にはf $f q$ の陽な関数として求めることができず，それゆえ $F$ もfを解析的に積分して求めることができない.

しかし， gは $h$ で積分可能であるとしているので, ある単位幅流量 $q(x)$ に対応する水量 $h(x)$ (図一2右) を求めることができれば, $F(q(x))$ は次式を用いて 求めることができる.

$$
F(q(x))=q(x) h(x)-\int_{0}^{h(x)} g(h) d h
$$

そこで，以下のような手順でsを計算することに する．まず，ある降水強度 $r$ を仮定する，すると， 降水流出系が定常であるとの仮定から，(10)式を用い て対象とする斜面素片の上下端での単位幅流量 $q$ (0), $q(L)$ を計算することができる。つぎに，そ の単位幅流量に対応する水量 $h(0), h(L)$ を数值的 に求める。最後に，(12)式を用いて $F(q(0)), F(q$ $(L))$ を求め，(11)式加を計算する，以上の手順に 上れば,一つの斜面素片の貯留量を求めるのに必要 な数值計算の回数は, 斜面素片上端と下端の水量を 求める計算の二回ですむ.

このようにして，降水強度てに対するすべての斜 面素片の貯留量を計算し, 対象とする山腹斜面系全 体の貯留量を求める. 一方, 降水強度皇に対する山

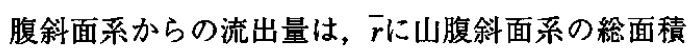
を乗じることで容易に求まる．この手順を，降水強 度の值を変えて繰り返し, 様々な降水強度に対応す る眝留量と流出量の関係を求めておく。こうして求 めた貯留量と流出量の離散的な関係を運動方程式と 見立てて流出計算を行なう。離散值の間は線形補間 で内挿する.

以上が筆者らの提案している集中化手法の概要で ある、2、では, この手法を基礎として, 固場容水 量を考慮した流量流積関係式に対する集中化手法を 展開する。

\section{2. 圈場容水量を考慮した流量流樌関係式の集中化 1) 概 説}

1.で述べたように，筆者らの集中化手法では, $q$ が直接的にhの関数であることを前提としていた が, 固場容水量を考慮した流量流積関係式では, 関 係する状態量として, $q, h$ のほかに, $h$ が存在し ているため, 本手法をそのまま適用することはでき ない. 本手法は, $h$ が $q$ の関数として表されていな いことに起因する困難を解決しているが，ここでは， さらに $q$ とhの媒介変数である $h_{f}$ の存在にも配慮す る必要がある。

1.で述べた集中化手法の本質は，(11)，(12)式にあ る.すなわち，任意の流量に対する $F$ を計算するこ とができれば，(11)式を用いて斜面素片の貯留量を計 算することができる．ここでは，固場容水量を考虑 した流量流積関係式から $\boldsymbol{F}$ を算出する方法を示す. (12)式を次に再記する.

$$
F(q(x))=q(x) h(x)-\int_{0}^{h(x)} g(h) d h
$$

この式で問題となるのは, 右辺第二項の積分部分 である. 右辺第一項については, $q(x)$ に対応するh $(x)$ を数值計算などで求めることにしているので, 容易に計算することができる，以下では，右辺第二 項の計算方法を中心に説明する。

(13)式の右辺第二項を $G_{1}$ と書くことにする．G $G_{1}$ の積 分をhによる積分から $h_{f} に よ る$ 積分に変換すると， 次式のように書き改めることができる.

$$
\begin{aligned}
G_{1} & =\int_{0}^{h_{f}(x)} g\left(h_{f}\right) \frac{d h}{d h_{f}} d h_{f} \\
& =\int_{0}^{h_{f}(x)} g\left(h_{f}\right) u^{\prime}\left(h_{f}\right) d h_{f}
\end{aligned}
$$

ただし, $h_{f}(x)$ は $h(x)$ に対応する自由水分水量であ $\eta$ ，また， $u\left(h_{f}\right), g\left(h_{f}\right)$ はそれぞれ(2)，(3)式で与え られるものである。'(ダッシュ)は能による微分を 意味する.

以下 $G_{1} を$, 表土層が不飽和の場合と飽和の場合で 区別して求める.

2) 不飽和時における集中化

(14)式は部分積分の関係より,

$$
\begin{aligned}
G_{1} & =\int_{0}^{h_{f}(x)} g\left(h_{f}\right) u^{\prime}\left(h_{f}\right) d h_{f} \\
& =\left[g\left(h_{f}\right) u\left(h_{f}\right)\right]_{0}^{h^{\prime}(x)}-\int_{0}^{h^{\prime}(x)} g^{\prime}\left(h_{f}\right) u\left(h_{f}\right) d h_{f}
\end{aligned}
$$




$$
=g\left(h_{f}(x)\right) u\left(h_{f}(x)\right)-\int_{0}^{h_{f}(x)} g^{\prime}\left(h_{f}\right) u\left(h_{f}\right) d h_{f}
$$

と毒くことができる．ここでさらに上式右辺第 2 項 を $G_{2}$ とおき，表土層が不飽和 $\left(0 \leq h_{j} \leq d\right)$ であること に留意して計算すると，

$$
\begin{aligned}
G_{2} & =\int_{0}^{h_{j}(x)} g^{\prime}\left(h_{f}\right) \boldsymbol{u}\left(h_{f}\right) d h_{f} \\
& =\int_{0}^{h_{f}(x)} a\left\{h_{f}+h_{c}\left(1-\left(\frac{d-h_{f}}{d}\right)^{M}\right)^{1 / N}\right\} d h_{f} \\
& =\frac{1}{2} a\left[h_{f}^{2}\right]_{0}^{h_{0}^{(x)}}+a h_{c} \int_{0}^{h_{f}(x)}\left(1-\left(\frac{d-h_{f}}{d}\right)^{N}\right)^{1 / N} d h_{f} \\
& =\frac{1}{2} a h_{f}(x)^{2}+a h_{c} \int_{0}^{h_{f}(x)}\left(1-\left(\frac{d-h_{f}}{d}\right)^{N}\right)^{1 / N} d h_{f}
\end{aligned}
$$

\section{となる。}

さらに上式の右辺第 2 項を

$$
G_{3}=\int_{0}^{h /(x)}\left(1-\left(\frac{d-h_{f}}{d}\right)^{M}\right)^{1 / N} d h_{f}
$$

とおく.ここで, $s=\left(d-h_{f}\right) / d$ とすると $d h_{f}=-d \cdot$ $d s$ となる．また, $h_{f}=0$ のとき $s=1, h_{f}=h_{f}(x)$ のと $き s=\left(d-h_{f}(x)\right) / d=c$ (定数： $\left.0<c<1\right)$ となるので, (17)式は次式のように書き直すことができる.

$$
G_{3}=d \int_{c}^{1}\left(1-s^{N}\right)^{1 / N} d s
$$

ここで, $v=1-s^{N}$ とおいて両辺を微分すると， $d v=-N s^{N-1} d s, d s=-1 / N s^{1-N} d v て ゙ あ り ， ま た, ~ s^{N}$ $=1-v, s=(1-v)^{1 / N}$ であるから,

$$
\begin{aligned}
d s & =-\frac{1}{N}(1-v)^{\frac{1-N}{N}} d v \\
& =-\frac{1}{N}(1-v)^{\frac{1}{N}-1} d v
\end{aligned}
$$

を得る。また, $s=1$ のとき $v=0, s=c$ のとき $v=$

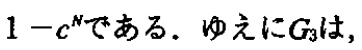

$$
\begin{aligned}
G_{3} & =d \int_{1-c^{*}}^{0} v^{\frac{1}{N}}\left\{-\left(\frac{1}{N}\right)(1-v)^{\frac{1}{N}-1}\right\} d v \\
& =\frac{d}{N} \int_{0}^{1-c^{N}} v^{\frac{1}{N}}(1-v)^{\frac{1}{N}-1} d v
\end{aligned}
$$

となる.

(20)式の積分部分は, ベー夕関数 $\beta\left(\frac{1}{N}+1, \frac{1}{N}\right)$ と 不完全ベー夕関数 $I_{1-c^{N}}\left(\frac{1}{N}+1, \frac{1}{N}\right)$ の積であり， $B_{1-c^{N}}\left(\frac{1}{N}+1, \frac{1}{N}\right)$ と表される.

以上を整理すると

$$
\begin{aligned}
& F(q(x))= \\
& \quad \frac{1}{2} a h_{j}(x)^{2}+a h_{c} \frac{d}{N} \cdot B_{1-c^{N}}\left(\frac{1}{N}+1, \frac{1}{N}\right)
\end{aligned}
$$

を得る(図一 3 ).

\section{3）飽和時における集中化}

(14)式の積分区間を $[0 \sim d]$ (表土層内) と $\left[d \sim h_{f}\right.$ $(x)]$ (地表面より上の部分)に区分して贵き改めると, $G_{1}=$

$$
\int_{0}^{d} g\left(h_{f}\right) u^{\prime}\left(h_{f}\right) d h_{f}+\int_{d}^{p(x)} g\left(h_{f}\right) u^{\prime}\left(h_{f}\right) d h_{f}
$$

となる.ここで,

$$
G_{4}=\int_{0}^{d} g\left(h_{f}\right) u^{\prime}\left(h_{f}\right) d h_{f}
$$

とすると，

$$
\begin{aligned}
G_{4}= & g(d) u(d)-\int_{0}^{d} g^{\prime}\left(h_{f}\right) u\left(h_{f}\right) d h_{f} \\
= & a d\left(d+h_{c}\right) \\
& -\int_{0}^{d} a \cdot\left\{h_{f}+h_{c}\left(1-\left(\frac{d-h_{f}}{d}\right)^{N}\right)^{1 / N}\right\} d h_{f} \\
= & a d\left(d+h_{c}\right)-\frac{1}{2} a\left[h_{f}^{2}\right]_{0}^{d} \\
& -a h_{c} \int_{0}^{d}\left(1-\left(\frac{d-h_{f}}{d}\right)^{N}\right)^{1 / N} d h_{f}
\end{aligned}
$$

となるが, 上式の右辺第 3 項の積分部分は，(17)式で 与えられる $G_{3}$ の積分区間を $[0 \sim d]$ としたものと 同一である. (17)式は変形されて最終的に(20)式の形に なり, また $h_{f}(x)=d$ のとき(20)式中の定数 $c$ は 0 とな るので, 上式右辺第 3 項の積分部分は(20)式に $c=0$ を代入したもの，つまり，

$$
\begin{aligned}
& \int_{0}^{d}\left(1-\left(\frac{d-h_{f}}{d}\right)^{N}\right)^{1 / N} d h_{f} \\
& =\frac{d}{N} \int_{0}^{1} v^{\frac{1}{N}}(1-v)^{\frac{1}{N}-1} d v \\
& =\frac{d}{N} \cdot B_{1}\left(\frac{1}{N}+1, \frac{1}{N}\right)
\end{aligned}
$$

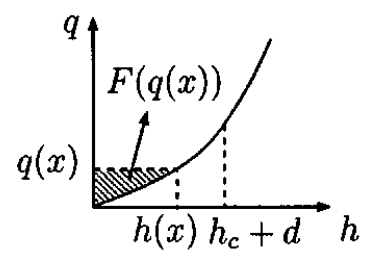

図一 3 不飽和の場合

Fig. 3 Calculation of $F$ under unsaturated condition 


$$
=\frac{d}{N} \cdot B\left(\frac{1}{N}+1, \frac{1}{N}\right)
$$

となる、ゆえにG

$$
G_{4}=\frac{1}{2} a d^{2}+a d h_{c}-a h_{c} \frac{d}{N} \cdot B\left(\frac{1}{N}+1, \frac{1}{N}\right)
$$

となる。

一方，(22)式の右辺第 2 項を $G_{5}$ と晴くことにすると， (2), (3)式 よ り $, q=g\left(h_{f}\right)=\alpha\left(h_{f}-d\right)^{m}+a h_{f}, h=u$ $\left(h_{f}\right)=h_{f}+h_{c}$ であるから,

$$
\begin{aligned}
G_{5} & =\int_{d}^{h_{f}(x)} g\left(h_{f}\right) u^{\prime}\left(h_{f}\right) d h_{f} \\
& =\int_{d}^{m(x)}\left\{\alpha\left(h_{f}-d^{m}\right)+a h_{f}\right\} d h_{f} \\
& =\frac{\alpha}{m+1}\left[\left(h_{f}-d\right)^{m+1}\right]_{d}^{h^{(}(x)}+\frac{1}{2} a\left[h_{f}^{2}\right]_{d}^{m_{d}^{(x)}} \\
& =\frac{\alpha}{m+1}\left(h_{f}(x)-d\right)^{m+1}+\frac{1}{2} a\left(h_{f}(x)^{2}-d^{2}\right)(27)
\end{aligned}
$$

となる。

これらを整理すると,

$$
\begin{aligned}
& F(q(x))= \\
& q(x) h(x)-a d h_{c}+a h_{c} \frac{d}{N} \cdot B\left(\frac{1}{N}+1, \frac{1}{N}\right) \\
& -\frac{\alpha}{m+1}\left(h_{f}(x)-d\right)^{m+1}-\frac{1}{2} a h_{f}(x)^{2}
\end{aligned}
$$

を得る(図一 4).

\section{4) 集中化手法のまとめ}

以上のようにして求めた $F(q(x))$ を用いて各斜面 素片の貯留量 $s$ 算出する手順をまとめると次のよ うになる。

1. ある降水強度 $r$ を仮定し, (10)式から斜面素片 上端および下端の単位幅流量 $q(0), q(L)$ を計 算する.

2. (3)式加 $5 q(0), q(L)$ に対応する自由水分水 量 $h_{f}(0), h_{f}(L)$ を数值的に計算する.

3. その自由水分水量に対応する水量 $h(0), h$

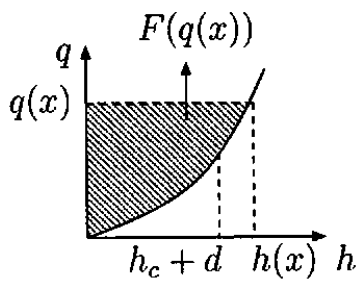

図一 4 䭒和の埸合

Fig. 4 Calculation of $F$ under saturated condition
（L）を(2)式を用いて求める.

4. $h_{f}(0), h_{f}(L)$ の值に応じて(21)，(28)式を用いて $\boldsymbol{F}(\boldsymbol{q}(0)), \boldsymbol{F}(\boldsymbol{q}(L))$ を計算する.

5. (11)式を用いて当該斜面素片の貯留量 $s$ 求め る.

この手順ですべての斜面素片の貯留量を算出 し，1. で示した手法と同様にして山腹斜面系全体 の貯留量と流出量の関係を求める.

以上が戋場容水量を考慮した流量流積関係式に対 する集中化手法である。この集中化手法を用いて導 出したモデルのことを本論文では集中化モデルとよ ぶことにする．Ｉ．では，集中化モデルを用いて流 出シミュレーションを行ない, 本モデルの有効性と 問題点を検証する。

\section{IV. 集中化モデルの適用}

\section{1. 大戸川流域への適用}

1) 流域の概要とモデル化

前節で導出した集中化モデルを大戸川流域に適用 する. 大戸川は淀川水系に属しており，筆者らの集 中化手法に関する一連の研究 $(1999 ; 2000)$ で適用対 象としてきた河川流域である．流域面積は $189.5 \mathrm{~km}^{2}$, 河床の平均勾配は, 下流部で約 $1 / 250$, 上流部では $1 / 250$ から $1 / 100$ である. 図一 5 に大戸川流域の模 式図を示す。モデルの適用領域は，大鳥居(お㧍と りい)地点より上流の流域 (148.9 $\left.\mathrm{km}^{2}\right)$ である.

まず，筆者ら (2000) と同様にして大戸川流域の数 值地形モデルを作成し，これをもとに対象域を 7 個 の部分流域(図一 5 中の一点鎖線と流域界に囲まれた領 域， 口の中の数字は部分流域の番号)に分割した。 そ して，各部分流域の斜面域に。で導出した集中化 モデルを適用した．河道網に対しては河道網集中型 kinematic waveモデル（高棹ら，1994）を適用した。 斜面域のモデルパラメ夕値として, $n: 0.6 \mathrm{~m}^{-1 / 3} \mathrm{sec}$, $m: 1.667, k: 0.015 \mathrm{~m} / \mathrm{sec}, \gamma_{\mathrm{e}}: 0.2, \gamma_{\mathrm{c}}: 0.1$, $D: 1.0 \mathrm{~m}, N: 6$ を用い, 河道網集中型 kinematic waveモデルのパラメタ值として, 粗度係数: 0.05 $\mathrm{m}^{-1 / 3} \mathrm{sec}$ 用いた。これらのパラメタのうち, $n$ と $N$ については，1990年 9 月19日から22日にかけて得ら れたデー夕(下記のケース 2)を入力として集中化モ デルで流出計算を行ない, 計算結果と観測值がよく 一致するように試行錯誤的に同定した．残りのパラ メタについては, 椎葉(1983)や日野ほか(1989)など の文献、これまでの経験などに基づいて定めた．ま た，比較のため，(2)，(3)式と連続式から構成される 


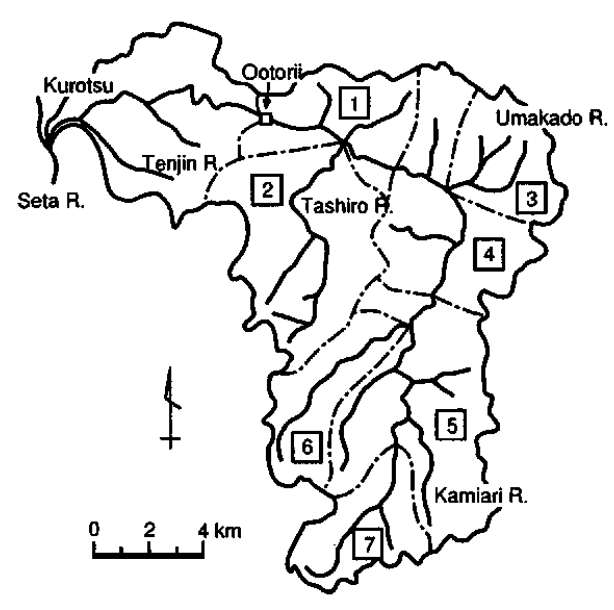

図一 5 大戸川流域

Fig. 5 Daido River basin

分布型モデルを用いた計算もあわせて行なった。パ ラメタ值は集中化モデルと同じものを用いた.

\section{2) 適用期間}

適用期間は，1982年 8 月 1 日〜 3 日(ケース 1), 1990年 9 月19日〜22日(ケース 2)とした。ケース 1 は台風10号が襲来した時期である. 台風10号は, 8 月 1 日に日本の南海上を北上し，2 日 0 時ごろ愛知 県渥美半島西部に上陸した後, 本州中部を北上して 2 日朝には日本海に進んだ。31都道府県に被害をも たらし，全国で95名の死者・行方不明者を出してい る. 近畿地方においても8月1日から3日にかけて かなりの降水量が観測され，大戸川流域に位壃する AMeDAS信楽観測所 (滋賀県甲賀郡信楽町)では, 8 月 1 日の日降水量が $235 \mathrm{~mm}$ となり, 観測開始以来の 最大值を記録している．ケース 2 は台風 19 号が雔来 した時期である. 台風19号は，9月17日から18日に かけて沖縄近海を北上し, 九州の南海上に達した。 この影響で秋雨前線が活発化し，17日は全国的に雨 が降り，18日も西日本を中心に $100 \mathrm{~mm} \sim 300 \mathrm{~mm}$ の大雨 となったところが多かった. 近畿地方では, 台風が 19日夜紀伊半島に上陸したため風雨が強まり, AMeDAS信楽観測所では19日の日降水量が126m と 比較的大きな值を記録している。

適用に際して使用した水文データは, 時間降水量 データおよび時間流量データである．ともに，建設 省 (当時, 現国土交通省, 以下同じ)所管大鳥居観測所 で得られたものである，なお，今回の適用にあたっ ては, 有効降雨と損失降雨の分離は行なわず, 観測 された降雨データをそのまま用いている。

\section{3）適用結果と考察}

図一6，7は，それぞれ，ケース 1，ケース $2 に$ おける計算流量と観測流量を比較したものである. いずれも, 実線は集中化モデルによる計算流量, 点 線は分布型モデルによる計算流量, 破線は観測流量, ステップ状の破線は観測降雨である.

まず，ケース1の結果について考察する．图一6 をみると, 計算開始後 6 時間から18時間あたりで集 中化モデルと分布型モデルの計算結果の違いが大き くなっているが, その後はよく一致している．また， 観測流量と比較すると, 全体的に観測流量のほうが 計算流量よりも大きくなっている，観測流量から直 接流出量に対する流出率を計算したところ1.0076と なり，若干ではあるが1を超える値となったことか ら, 観測流量が実際の流量よりも過大であったか, あるいは観測降雨が過小であった可能性も考えられ る(ちなみにケース 2 では0.74となった).

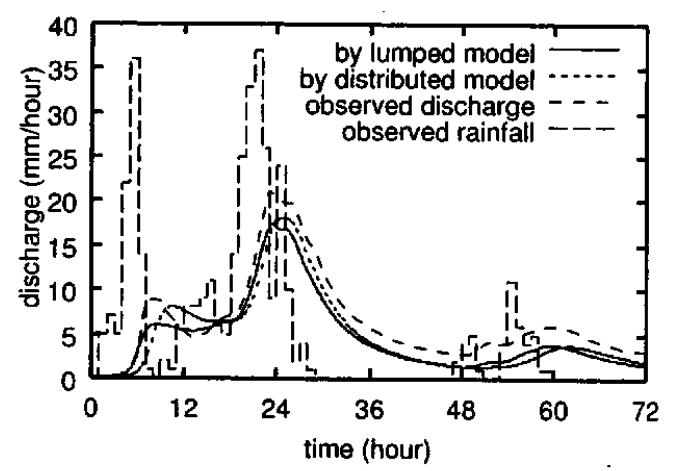

図一6 計算流是と観測流量 (ケース 1)

Fig. 6 Calculated and observed hydrographs (case 1)

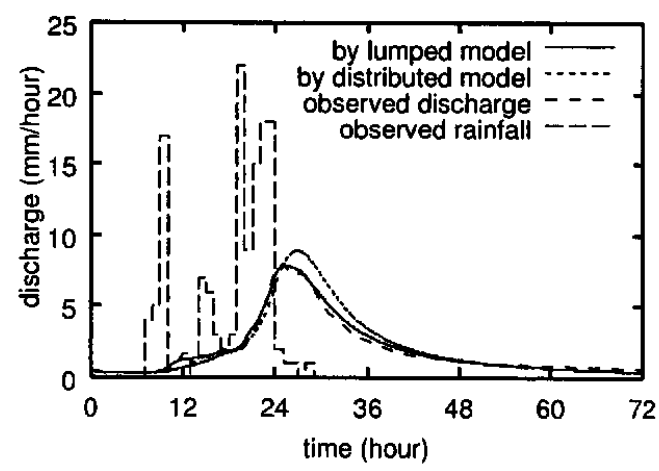

图一７計策流量と観測流量(ケース 2)

Fig. 7 Calculated and observed hydrographs (case 2) 
つぎに，ケース 2 の結果について考察する．この ケースでは, 分布型モデルより集中化モデルのほう が観測結果とよく一致している。これは，先にも述 べたように，このケースのデータと集中化モデルを 用いてパラメ夕の同定を行なったためである．集中 化モデルの結果は, 降雨初期から降雨終了後に至る まで，観測值と非常によく一致している.

集中化モデルと分布型モデルの計算結果を比較す ると，降雨終了直後に大きな違いが現われている. 集中化モデルでは強い降雨が終了すると直ちに流量 が減り始めているのに対し，分布型モデルでは，そ の後も流量が増加し, しばらくしてから流量が減り 始めている．この違いの理由としては，集中化モデ ルでは定常状態における貯留量流出量関係を用いて いることが考えられる.ケース 2 では，18時間から 24時間あたりで強い降雨があり，その直後に一連の 降雨は終了している．このことから，降水流出系の 非定常性が強くなり, 集中化モデルと分布型モデル の特性の違いがはっきりと現われたものと推測され る.ここでは, 集中化モデルを用いてパラメ夕值を 同定したために集中化モデルのほうがよい結果を示 したが，分布型モデルでパラメ夕值を同定すれば, 集中化モデルの計算精度は悪化するものと思われる。 同じパラメ夕値を用いて両モデルからほほ同等の結 果を得るためには，集中化モデルにおいても流出過 程の非定常性を考感できるような方法を考える必要 がある。このことについては，2，でも再度述べる．

また, 本研究では, CPU : Intel Celeron 400 $\mathrm{MHz}$,メモリ:64MB, OS:FreeBSD 3.3, コン パイラ：gcc ver. 2.7.2.3という構成の計算機を用 いてシミュレーションを行なった. ケース1におい て集中化モデルと分布型モデルの計算時間を実時間 で比較したところ, 分布型モデルが約4.5時間で あったのに対し，集中化モデルでは約10分となり， 計算時間を大幅に短縮することができた。

\section{2. 桂川流域への適用}

1) 流域の概要とモデル化

集中化モデルを桂川流域に適用し, 分布型モデル の計算結果および観測値と比較する．桂川は大戸川 と同じく淀川水系に属し, 流域面積は $875 \mathrm{~km}^{2}$ (建設 省桂観測所より上流)である．ここで対象とするのは， 建設省亀岡観測所より上流の流域 $\left(710.22 \mathrm{~km}^{2}\right)$ であ る.この対象領域を河道区分の集水域ごとに分割し， 各集水域の斜面域に、で導出した集中化モデルを
適用した，桂川流域の模式図を図一8に示す。

本シミュレーションでは, 鎌倉, 周山, 殿出, 園 部, 新町, 西別院の各建設省雨量観測所と, $\mathrm{AMeDAS}$ 京北観測所で得られた時間雨量データを 使用した。 大戸川流域への適用と同様に，有効降雨 と損失降雨の分離は行なわず, 観測された降雨デー タをそのまま使用した．流量データは，建設省所管 の世木ダム観測所と亀岡観測所で得られたものを用 いた。世木ダム観測所では，ダムへの流入量とダム からの放流量の二種類の流量データが計測されてい るが，それらを比較したところ，ほとんど違いがな かったので，ここではダムへの流入量デー夕を使用 している．また，流入量と放流量の差がほとんど認 められなかったことから，このダムによる河川流況 への影響は無視しうると判断し，世木ダムのモデル を流域全体系のモデルに組み込むことはしていない． また，この流域には，平成10年(1998年)に日吉ダム が完成し，その後運用が開始されているが, 次に述 ベるように，今回のシミュレーションの対象時期は 日吉ダム完成前の1989年であるため, 当然ではある が, 日吉ダムのモデルも流域全体系のモデルには組 み达まれていない.

斜面域のモデルパラメ夕值としては, $n: 0.6 \mathrm{~m}^{-1 / 3}$

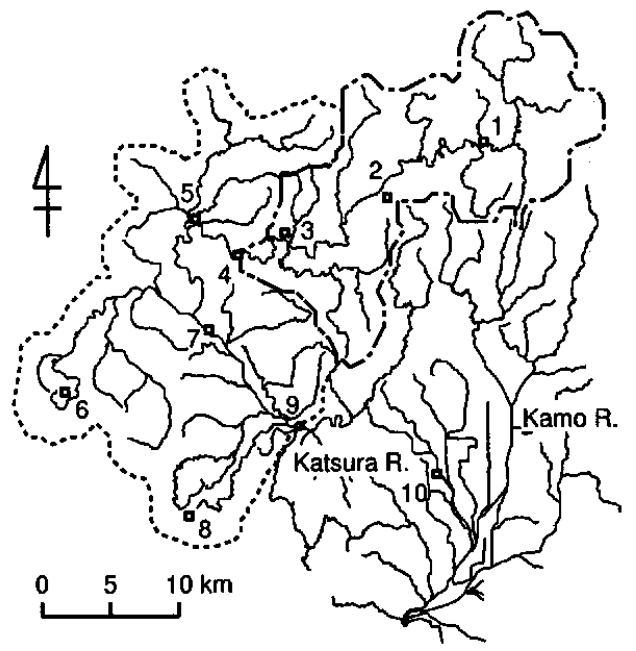

図一8 桂川流域，1：鎌倉， 2 : 京北，3：周山, $4:$ 世木夕゙ム, $5:$ 殿田, $6:$ 園部, $7:$ 新 町, $8:$ 西別院, 9:亀岡, $10:$ 桂

Fig. 8 Katsura River basin, 1: Kamakura, 2: Keihoku, 3: Shuuzan, 4: Seki dam, 5: Tonoda, 6: Sonobe, 7: Shinmachi, 8: Nishibetsuin, 9: Kameoka, 10: Katsura 
sec, $m: 1.667, k: 0.015 \mathrm{~m} / \mathrm{sec}, \gamma_{c}: 0.3, \gamma_{c}:$ $0.1, D: 1.0 \mathrm{~m}, N: 6$ を用いた。 また, 河道の計 算には，1，とは違って，河道網集中型kinematic waveモデルではなく，分布型のkinematic waveモ デルを用いた．河道の粗度係数は， $0.03 \mathrm{~m}^{-1 / 3} \mathrm{sec}$ と した。

\section{2 ）適用期間}

適用期間は，1989年 9 月 2 日から 4 日である。こ の期間においては，東シナ海上に低気圧が発生し， 発達しながら東に進んで，九州，山陰，四国，近畿， 東海の広い範囲に強雨をもたらした，この雨で，九 州を中心に 2 府16県で水害が発生し，7名の死者が 出た，大阪では， 9 月 3 日の日雨量が $174 \mathrm{~mm}$ となり， 日雨量の 9 月第一位を記録している。

\section{3）適用結果と考察}

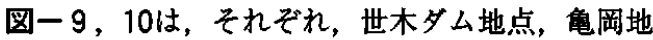
点において，集中化モデルの計算結果，分布型モデ ルの計算結果, 観測流量を比較したものである. 実 線が集中化モデルの計算結果, 点線が分布型モデル の計算結果, 破線が観測流量, ステップ状の破線が 観測雨量である．観測雨量については，図ー9では $\mathrm{AMeDAS}$ 京北観測所で, 図一10では建設省新町観 測所で得られたデータを表示している.

図一9，10を見ると，集中化モデル，分布型モデ ルともに，あまり良好な結果が得られていない。世 木ダム地点(図一9)では，流量時系列の形状(流量の 立上り時刻，ピーク時刻なと゚），降雨終了後における 流量の低減部はよく再現されているものの, 総流出 量が観測值にくらべて過大となっている．亀岡地点 (図一10)では，総流出量は観測值に近くなっている が，流量時系列の形状があまり一致しておらず，集 中化モデルの計算結果, 分布型モデルの計算結果と もに，観測値にくらべて流量の減り始める時刻が2 時間ほど早くなっている。 この原因が, 斜面系のモ デルにあるのか, 河道網系のモデルにあるのか, 残 念ながら明らかではない，筆者らはこれまで，流域 流出系のモデルを構成する場合，対象とする流域を 斜面系と河道網系に分けてモデル化するという手法 をとってきた．この手法は，流域流出系の構造に即 しており，对象流域を一括してモデル化する手法に くらべれば，自由度が高く，様々な発展性を持って いると考えるが，しかし実際のところ，斜面系から の流出量を観測する手立てがないため，斜面系，河 道網系それぞれのモデルを分けて同定・検定するこ とができない。この手法をより一層発展させていく
ためには，斜面系からの流出量を河川流量の観測値 から推定する手法もあわせて關発していく必要があ ると考えられる。

集中化モデルと分布型モデルの計算結果を比較す ると，両者は扔执むね一致しているが，1．でも見 られたように，集中化モデルのほうが分布型モデル に比べて降雨に対する応答が敏感で，降雨終了直後， あるいは, 強い降雨のあとに, 両計算結果の差が大 きくなっている。これは，すでに述べたように，本 集中化手法の原理そのものに根ざしたものと考えら れる.この問題を本質的に解決するためには，集中 化モデルにおいても雨水流下過程の非定常性をある 程度考虑できるような方法を考えなければならない。 たとえば，斜面系を上端から下端までまとめて集中 化するのではなく，雨水の流下方向に沿って斜面系 をいくつかの領域に分割したうえで集中化手法を適 用し，各領域に対応する集中化モデルを多段階に接

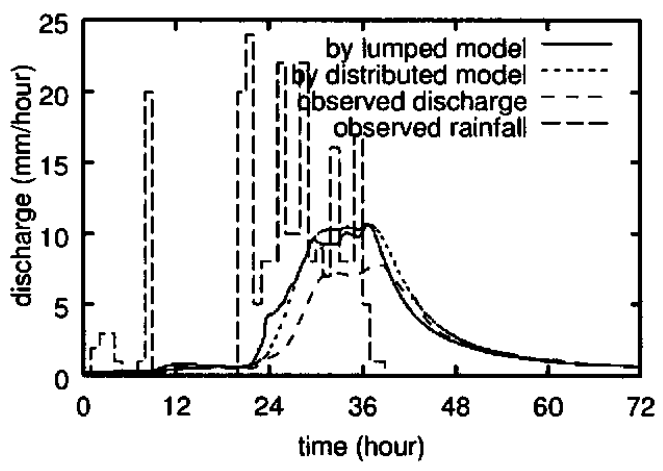

\section{図ー9 流量の比較(世木ダム地点)}

Fig. 9 Calculated and observed hydrographs at Seki dam

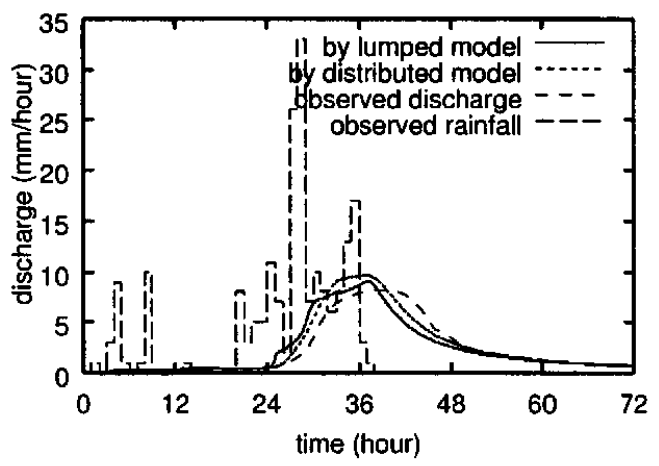

図一10 流量の比単 (岡地点)

Fig. 10 Calculated and observed hydrographs at Kameoka 
続することで, 雨水流下過程を追跡計算する方法な どが考えられる。

\section{V.おわりに}

本論文では，筆者らがこれまで展開してきた，山 腹斜面流出系に対する流量流積関係式を集中化する 手法を用いて, 椎葉ら(1998)が開発した, 固場容水 量を考虑した流葍流積関係式を集中化する方法につ いて述べた。

II.では，固場容水量を考悉した流量流積関係式 について説明し，III。では,この流量流積関係式を 集中化する手法を具体的に示した. 筆者らが展開し てきた集中化手法では, 単位幅流量 $q$ が直接的に水 量hの関数であることを前提としていたが, 围場容 水量を考㦄した流量流積関係式では，関係する状態 量として, $q, h$ のほかに, 自由水分水量 $h_{f}$ 多存在し ている，そこで, 本集中化手法の本質である(13)式を, hの存在に配慮しつつ計算する手法を示した。

IV.では，III.で導出した集中化モデルを大戸川 流域と桂川流域に適用した。 大戸川流域では，集中 化モデル・分布型モデルの両計算結果と観測值は比 較的よく一致した. とくに, 無降雨時の流量低減過 程をよく再現することができ，また，三日分の計算 に, 分布型モデルでは約4. 5時間要したのを, 集中 化モデルでは約10分に短縮することができた。一方， 桂川流域では，あまり良好な結果を得ることはでき なかった. 流域内の二地点で計算流量と観測流量を 比較したが, 上流の世木ダム地点では計算流量が過 大となり, 下流の龟岡地点では計算値のほうが観測 值よりも早く流量が減り始めるという結果になった. 以上の傾向は集中化モデルだけではなく，分布型モ デルのほうでも認められるため，集中化によって生 じた誤差というわけではない.ただ，この誤差が斜 面系のモデルによるものか，河道網系のモデルによ るものか明らかではない. 斜面系からの流出量を河 川流量の観測值から推定する手法もあわせて開発し, 斜面系・河道網系の効果を分離したうえで，それぞ れのモデルの精度を高める努力が必要であると考え られる。

また，集中化モデル，分布型モデルの計算結果を 比較したところ, 降雨終了直後，あるいは，強い降 雨のあとに，両計算結果の差が大きくなることが明 らかとなった。これは，定常状態における貯留量流 出量関係を用いて流出計算を行なうという本集中化
手法の原理そのものに根ざしたものと考えられる. この問題を本質的に解決するためには，集中化モデ ルにおいても雨水流下過程の非定常性をある程度考 虑できるような方法を考えなければならない。たと えば，斜面系を上端から下端までまとめて集中化す るのではなく, 雨水の流下方向に沿って斜面系をい くつかの領域に分割したうえで集中化手法を適用し, 各領域に対応する集中化モデルを多段階に接続する ことで, 雨水流下過程を追跡計算する方法などが考 えられる。

さらに, 今回は強降雨時の出水だけを対象として シミュレーションを行なったが, 今後は降雨遮断や 蒸発散機構, 地下水流出機構などをモデルに導入す ることで，長期的なシミュレーションを行なうこと ができるよう研究をすすめていく予定である．

\section{参考文献}

日野幹雄・太田猛彦 - 砂田憲吾 - 渡辺邦夫(1989)：

洪水の数值予報, 森北出版株式会社.

市川 温・ 小椋俊博 - 立川康人・椎葉充晴 (1999)：

数值地形情報と定常状態の仮定を用いた山腹斜面 系流出モデルの集中化, 水工学論文集, 43, pp. $43-48$.

市川 温 - 小椋俊博 - 立川康人 - 椎葉充晴 - 宝 檠 (2000)：山腹斜面流出系における一般的な流量流 積関係式の集中化, 水工学論文集, 44, pp. 145 -150 .

椎葉充晴 (1983)：流出系のモデル化と予測に関する 基礎的研究, 京都大学博士論文.

椎葉充晴 - 立川康人・市川 温 - 堀 智晴 - 田中賢 治(1998)：围場容水量・パイプ流を考虑した斜面 流出計算モデルの開発, 京都大学防災研究所年報, 41, B-2, pp. 229-235.

椎葉充晴・市川温・榊原哲由・立川康人(1999 a): 河川流域地形の新しい数理表現形式, 土木学 会論文集, No. 621/II-47, pp. 1-9.

椎葉充晴 - 立川康人 · 田中賢治・市川 温 - 金澤瑞 樹 (1999b) : 大気・陸面過程モデルと山腹斜面水 文モデルの結合, 京都大学防災研究所年報, 42 , B-2, pp. 169-176.

高棹环馬・椎葉充晴・市川 温(1994)：分布型流出 モデルのスケールアップ, 水工学論文集, 38 , pp. $809-812$.

（受付：2001年 6 月18日，受理：2001年10月17日） 